Manuscript received February 28, 2014; accepted for publication July 8, 2014; published online October 7, 2014.

${ }^{1}$ M. ASCE, Assistant Professor, Civil Engineering Dept., Faculty of Engineering, Payame Noor of I.R. Iran, 9187995759, e-mail:

kazemian.s@pnum.ac.ir

2 M. ASCE, Postdoctorate Scholar, Geotechnics \& Transportation Dept., Faculty of Civil Engineering, Universiti Teknologi Malaysia, Skudai, Johor 81310, Malaysia, e-mail: hossein.moayedi@gmail.com

${ }^{3}$ Assistant Professor, Dept. of Civil and Environmental Engineering, Shiraz Univ., Shiraz, Iran, 7188834399, e-mail: mosalla578@yahoo.com
Sina Kazemian, ${ }^{1}$ Hossein Moayedi, ${ }^{2}$ and Mansour Mosallanezhad ${ }^{3}$

\section{The Effect of Cement-Sodium Silicate Grout Compounds on Void Ratio and the Coefficient of Secondary Compression of Treated Fibrous Peat}

\section{Reference}

Kazemian, Sina, Moayedi, Hossein, and Mosallanezhad, Mansour, "The Effect of Cement-Sodium Silicate Grout Compounds on Void Ratio and the Coefficient of Secondary Compression of Treated Fibrous Peat," Journal of Testing and Evaluation, Vol. 43, No. 2, 2015, pp. 279-285, doi:10.1520/JTE20140082. ISSN 0090-3973

\section{ABSTRACT}

Peats have low shear strength and high deformation characteristics. Peat is a naturally occurring material that is extremely soft with a high moisture content and exists in an unconsolidated state. The conventional binders used are cementitious materials, and the introduction of a new binder, sodium silicate, with other additives gives a better output than the conventional peat treatment. This article describes a laboratory study on the effect of different compounds of cement-sodium silicate grout on void ratio and the coefficient of secondary compression of fibrous peat. It is shown that by increasing the amount of sodium silicate (within $2.5 \%$ ), cement, and kaolinite in treated peat, we were able to decrease the mentioned properties of treated peat.

\section{Keywords}

fibrous peat, coefficient of secondary compression, void ratio, cement, sodium silicate, kaolinite

\section{Introduction}

The stabilization of highly organic soils such as peat is much more demanding than the stabilization of clay. The traditionally used cement, lime, and lime-cement mixtures are not necessarily the most suitable for these soils. Instead, mixtures of cement and granulated blast furnace slag are often used. These new binders have been extensively researched and tested both in the laboratory and in the field [1-3]. In addition, in most countries, the need for the consolidation of soft soil 
deposits and the use of different improvement materials or techniques is extensively high $[4,5]$. One of the problems with applying this technology to organic soils is that organic matter inhibits cementitious reactions. In fact, for all soils, inorganic and organic, the properties of the stabilized product are extremely difficult to predict, in part because of the lack of understanding of the reactions of the soil, water, and binding agent [6]. Therefore, construction on peat soils has proven to be a challenging task, as this soil is highly compressible, has a low strength, and retains neither its form nor its strength after oxidation.

Huge numbers of poor foundation conditions are reported in all areas of Malaysia where clay, mud, and peat deposits appear. Accordingly, intensive geotechnical research work on soil-improvement techniques in Malaysia is performed at three universities: Universiti Putra Malaysia [7-10], Universiti Teknologi Malaysia [11-13], and Universiti of Malaya [14-16]. Peat or peaty soil normally having a high organic matter content is generally associated with high compressibility and a high magnitude and rate of creep [17]. It may also be associated with poor strength characteristics and a risk of large deformation $[5,18]$. Thus, peat soil is often viewed as a problematic soil because its engineering properties are inferior to those of other soft soils. It poses serious problems in the construction industry because of its long-term consolidation settlement even when subjected to a moderate load $[7,19]$.

Anderssonl [1] investigated hydraulic cement-based binders for the mass stabilization of organic soils. He describes mass stabilization as a new, environmentally friendly soil improvement method in which stabilizer is mixed into peat, mud, or soft clay. The results have been encouraging, showing that it is possible to provide environmentally friendly solutions and stabilize organic soils cost-effectively. Edil and Fox [20] studied a field test of thermal precompression on peat. They presented a new concept for the improvement of soft ground using moderate heating to control post-construction settlement. Accordingly, they provided the long-term creep behavior of a peat based on laboratory oedometer tests involving step-stress and step-temperature changes. Finally, the feasibility of thermal precompression as a method of controlling or accelerating in situ settlement has been discussed. Hampton and Edil [6] investigated the strength gain of organic ground with cementtype binders. They presented a synthesis of mixture tests conducted in Delft, The Netherlands, and Madison, WI, on several peats and an organic clay showing that the current experimental techniques are not sufficient to create a comprehensive model of strength gain in stabilized organic soil. Research is needed on the fundamental chemical reactions contributing to changes in the geotechnical properties of stabilized organic ground [6]. DenHamer et al. [21] investigated the stabilization of peat by silica-based solidification. They developed a novel soil stabilization concept (called peat silicification) in which soil properties are modified in situ through encapsulation of the peat fibers with a layer of silicate. The results could increase strength and offer some resistance to biological and chemical oxidation. The silicification process involves the addition of three components: a cationic surfactant, a binding agent (a sodium metasilicate solution), and molasses to stimulate microbial fermentation, leading to the production of organic acids that will harden the geopolymer gel formed by the surfactant and binding agent. They achieved strengths of up to $1 \mathrm{MPa}$ (UCS) in the laboratory using this process.

The main aim of this study was to determine the effect of cement-sodium silicate grout compounds on the void ratio $(e)$ and the coefficient of secondary compression $\left(C_{\alpha}\right)$ of fibrous peats. Different ratios of grouts were tested in order to find the effect of each compound on the mentioned properties of fibrous peat.

\section{Materials and Methods}

Fibrous peat was collected from different locations in Kampung Jawa, Kelang, southwest of Kuala Lumpur, Malaysia. The physicochemical properties of fibrous peat are presented in Table 1. Ordinary Portland cement, kaolinite $\left[\mathrm{Al}_{2} \mathrm{Si}_{2} \mathrm{O}_{5}(\mathrm{OH})_{4}\right]$, sodium silicate, and calcium chloride were used to mitigate settlement problems in fibrous peat.

In order to determine the effects of different compounds on the compressibility parameters of fibrous peat, samples were prepared by mixing a specified amount (as a percentage) of cement, kaolinite, sodium silicate, and calcium chloride by weight of wet peat. The dosages of the various compounds used

TABLE 1 Physico-chemical characteristics of untreated fibrous peats.

\begin{tabular}{|c|c|c|}
\hline Parameters & Method & Fibrous Peat \\
\hline Fiber content, $\%$ & ASTM D1997-91 [22] & 79.1 \\
\hline Moisture content, \% & BS 1377: Part 2: 1990, Clause 3 [23] & 506.5 \\
\hline Specific gravity & BS 1377: Part 2: 1990, Clause 8.4 [23] & 1.26 \\
\hline Organic content, $\%$ & BS 1377: Part 3: 1990, Clause 4 [23] & 94.23 \\
\hline Bulk unit weight, $\mathrm{kN} / \mathrm{m}^{3}$ & BS 1377: Part 2: 1990, Clause 7 [23] & 9.86 \\
\hline Degree of humification, $\%$ & von Post [24] & $\mathrm{H}_{3}$ \\
\hline
\end{tabular}


FIG. 1 Rowe cell apparatus.

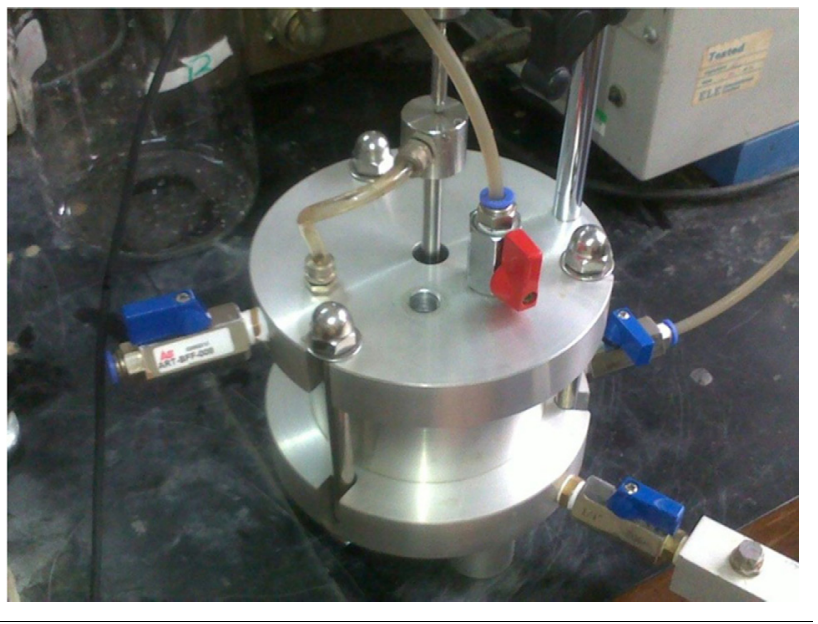

were as follows: cement, $5 \%, 10 \%, 20 \%$, and $30 \%$; kaolinite, $0 \%, 10 \%, 20 \%$, and $30 \%$; sodium silicate, $0 \%, 1 \%, 2.5 \%$, $3 \%$, and $5 \%$; and calcium chloride, $1 \%$. The samples were prepared by first mixing thoroughly homogenized peat at its natural water content with a household mixer and then adding the desired amounts of kaolinite, calcium chloride, cement, and sodium silicate. Three samples were prepared according to the percent weight of wet peat, as per the ratio of additives, and the average values of the results are reported. The samples were transferred to cylindrical containers and kept in a tray containing water. The compressibility parameters of fibrous peats, in vertical and horizontal directions, were evaluated with a Rowe cell according to BS 1377 Part 6: 1990 [23]. The Rowe cell apparatus is shown in Fig. 1.

\section{Results and Discussion}

\section{INFLUENCE OF ORDINARY PORTLAND CEMENT ON FIBROUS PEAT}

The variation in secondary compression for $20 \%$ and $30 \%$ cement and effective pressures ranging from 25 to $200 \mathrm{kPa}$ is shown in Fig. 2. It was observed that the coefficient of secondary compression $C_{\alpha}$ decreased with the increase in cement. The $C_{\alpha}$ of untreated peat was 0.122 at a pressure of $25 \mathrm{kPa}$. It decreased to 0.00023 and 0.00008 with $20 \%$ cement, and it decreased to 0.00008 with $30 \%$ cement at the same pressure. Further, $C_{\alpha}$ was observed to increase with an increase in effective pressure. For untreated peat, it increased from 0.122 to 0.187 when the pressure was increased from 25 to $200 \mathrm{kPa}$. Similarly, it increased from 0.00023 to 0.00052 when the effective pressure increased from 25 to $200 \mathrm{kPa}$ for samples with $20 \%$ cement and from 0.00008 to 0.0002 for the same increase in effective pressure for samples with $30 \%$ cement.

The variation in void ratio $e$ with an increase in cement content is shown in Fig. 3. The void ratio was observed to decrease with an increase in cement content. The void ratio, at an effective pressure of $10 \mathrm{kPa}$, was observed to decrease from 0.805 to 0.62 when the cement content increased from $20 \%$ to $30 \%$. For samples with $20 \%$ cement, it decreased from 0.805 to 0.79 when the effective pressure increased from 10 to $200 \mathrm{kPa}$. Similarly, for samples with $30 \%$ cement, it decreased from 0.62 to 0.61 when the effective pressure increased from 10 to $200 \mathrm{kPa}$. The void ratio was also observed to decrease with an increase in effective pressure for all samples.

Pozzolanic reaction is responsible for the long-term strength gain of stabilized soil, so in this case the pozzolanic reaction might not be the main factor, because the samples were
FIG. 2

Influence of cement concentration on coefficient of secondary compression of fibrous peat.

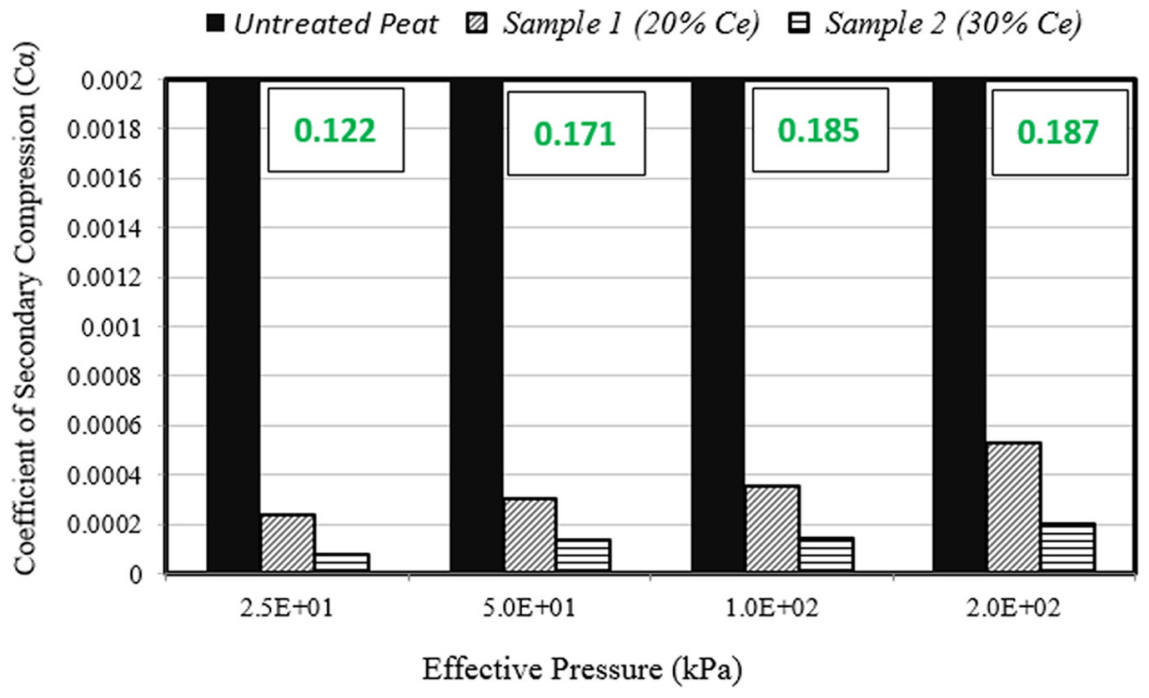


FIG. 3

Influence of cement concentration on void ratio of fibrous peat.

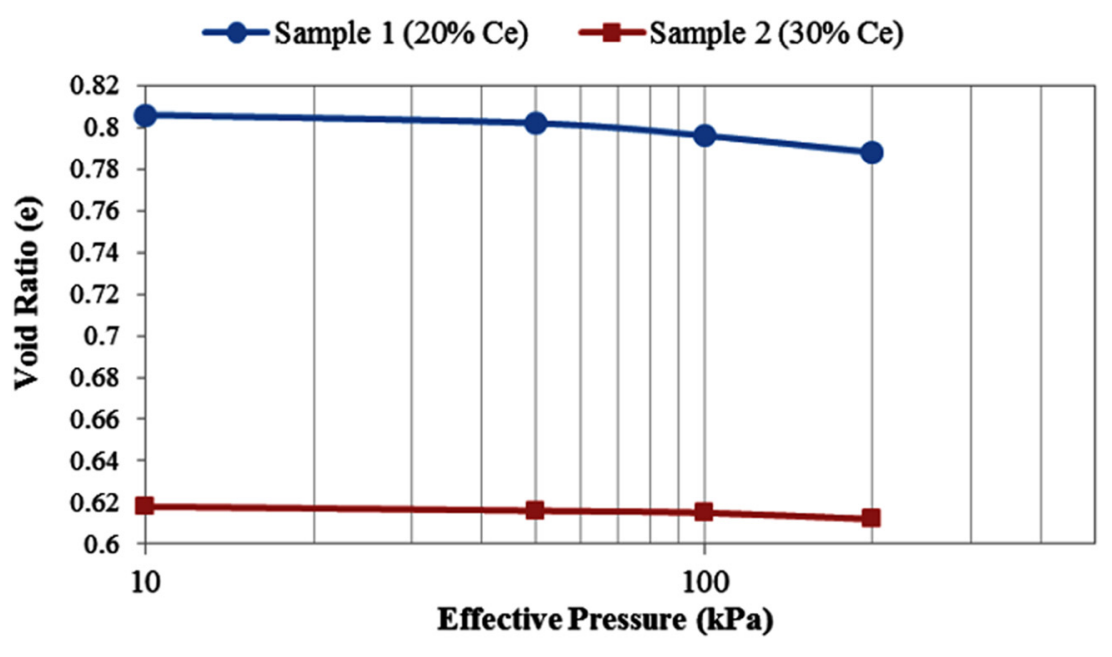

treated for less than a week. The ion exchange between calcium ions from cement and calcium chloride from kaolinite also would have decreased the mentioned parameters of the samples.

\section{INFLUENCE OF KAOLINITE ON FIBROUS PEAT}

The variation of $C_{\alpha}$ with effective pressure for samples with $10 \%, 20 \%$, and $30 \%$ kaolinite is shown in Fig. $4 C_{\alpha}$ was observed to gradually decrease as the percentage of kaolinite increased.

The $C_{\alpha}$ of untreated peat was 0.123 at an effective pressure of $25 \mathrm{kPa}$. With the addition of $0 \%, 20 \%$, and $30 \%$ kaolinite, it decreased to $0.0009,0.00022$, and 0.00007 , respectively. Similarly, the $C_{\alpha}$ of untreated peat increased with an increase in effective pressure from 0.123 at $25 \mathrm{kPa}$ to 0.187 at $200 \mathrm{kPa}$.
Similar variation in $C_{\alpha}$ was observed for samples with $0 \%$, $20 \%$, and $30 \%$ kaolinite when the pressure was increased from 25 to $200 \mathrm{kPa}$.

The variation in void ratio with an increase in kaolinite is shown in Fig. 5. The void ratio was observed to decrease with an increase in kaolinite and with an increase in effective pressure from $10 \mathrm{kPa}$ to $200 \mathrm{kPa}$.

The void ratio was found to be 1.1, 0.69, and 0.62 for samples with $10 \%, 20 \%$, and $30 \%$ kaolinite at an effective pressure of $10 \mathrm{kPa}$. The void ratio decreased with an increase in effective pressure for all samples. For samples with $10 \%$ kaolinite, the void ratio decreased from 1.1 to 1.04 when the effective pressure increased from 10 to $200 \mathrm{kPa}$. However, for samples with more kaolinite, the void ratio showed a very small reduction, from 0.69 to 0.68 and from 0.62 to 0.61 for samples with $20 \%$ and
FIG. 4

Influence of kaolinite concentration on coefficient of secondary compression of fibrous peat.

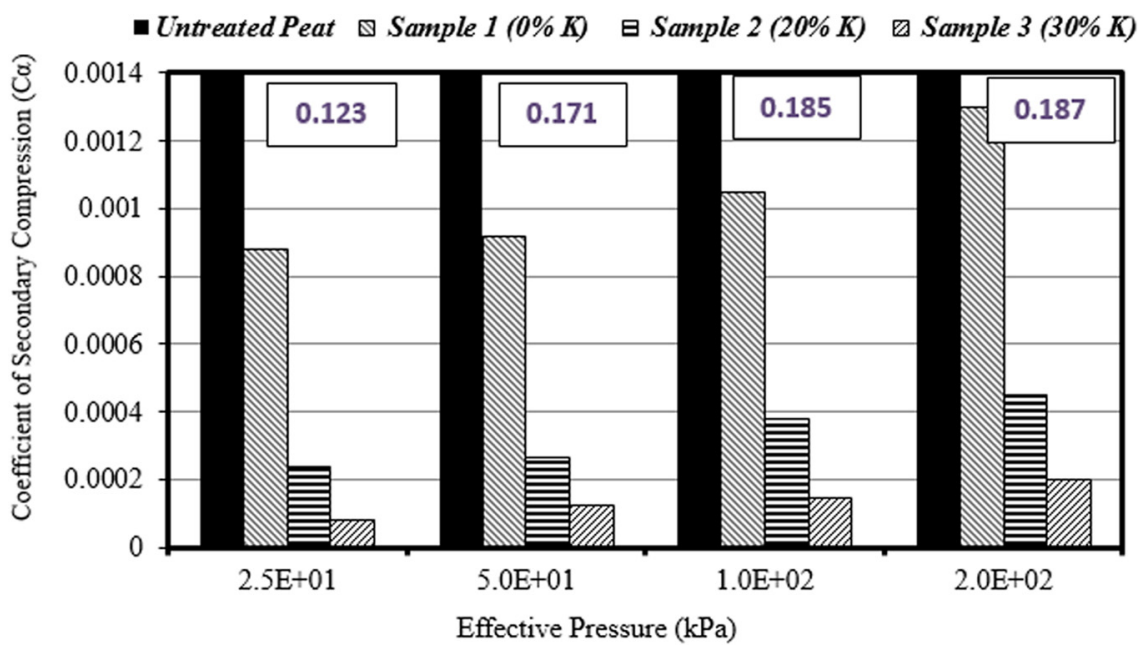


FIG. 5

Influence of kaolinite concentration on void ratio of fibrous peat.

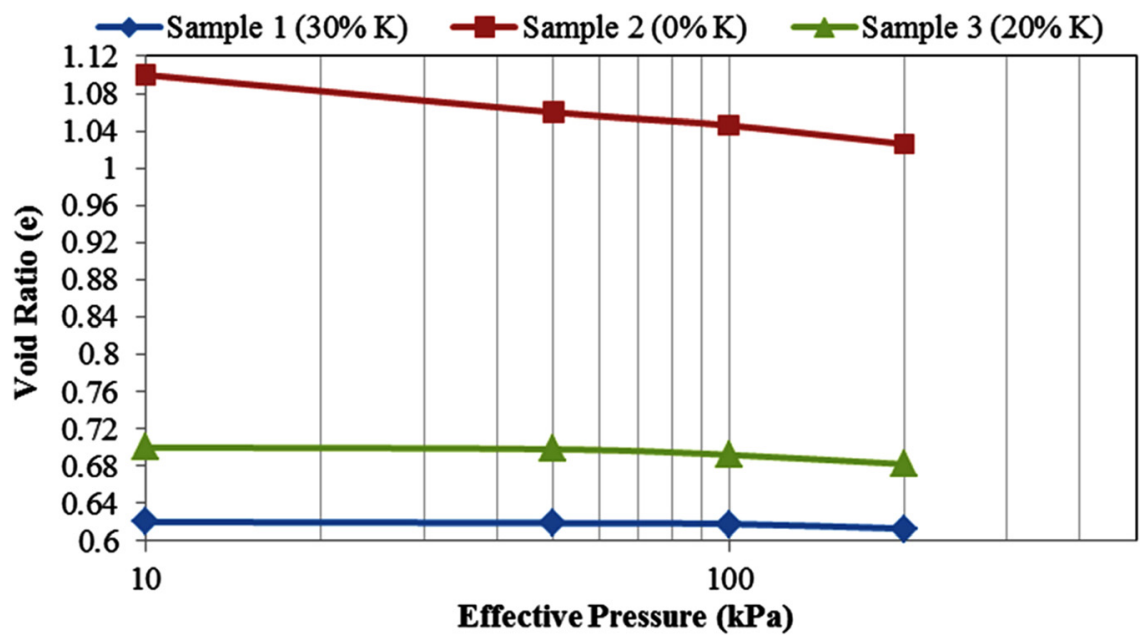

$30 \%$ kaolinite, respectively. The effect of kaolinite on the compressibility behavior is considered small relative to the effect of cement.

These results agree well with the published results; with the addition of kaolinite and calcium chloride, the adsorption of organic compounds will increase and calcium may create a bridge or connection (mentioned above) between the organic compound and the mineral part of fibrous peat and kaolinite $[9,10]$.

\section{INFLUENCE OF SODIUM SILICATE ON FIBROUS PEAT}

The variation in $C_{\alpha}$ with changes in sodium silicate content and effective pressure is shown in Fig. 6.

As observed from Fig. 6, the $C_{\alpha}$ decreased from 0.0008 to 0.0001 when the sodium silicate content increased from 0 to
$2.5 \%$ at an effective pressure of $25 \mathrm{kPa}$. With an increase in sodium silicate content from $2.5 \%$ to $5 \%$, a reversal in $C_{\alpha}$ was observed. It increased from 0.0001 to 0.0003 at the same pressure.

The void ratio, as shown in Fig. 7, decreased from 1.04 to 0.62 when sodium silicate was increased from 0 to $2.5 \%$. With a further increase in sodium silicate content, the void ratio increased, instead of decreasing, from 0.62 to 0.91 , indicating that the optimum dose of sodium silicate is $2.5 \%$.

This behavior could be due to the fact that the mixture of cement and sodium silicate in the presence of calcium chloride causes intensive hydration, and the $\mathrm{OH}^{-}$ions passing into the solution are consumed in the reaction of depolymerization and hydrolysis of silicate anions of the additives. When the concentration of calcium and hydroxide ions reaches a certain value,
FIG. 6

Influence of sodium silicate concentration on coefficient of secondary compression of fibrous peat.

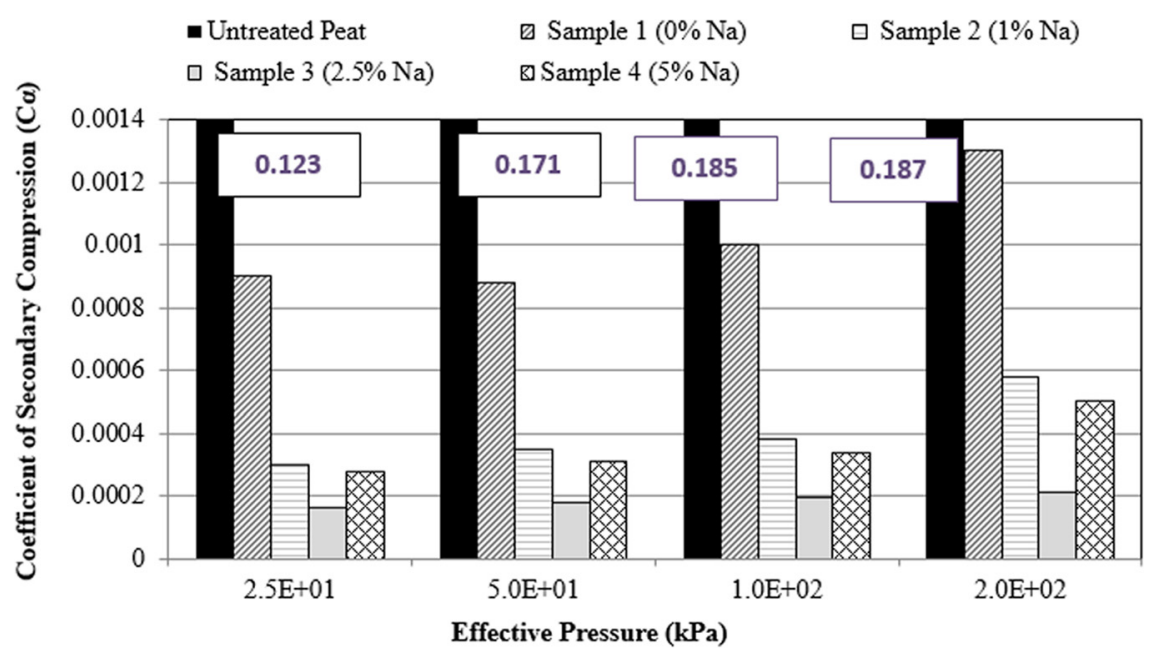


FIG. 7

Influence of sodium silicate concentration on void ratio of fibrous peat.

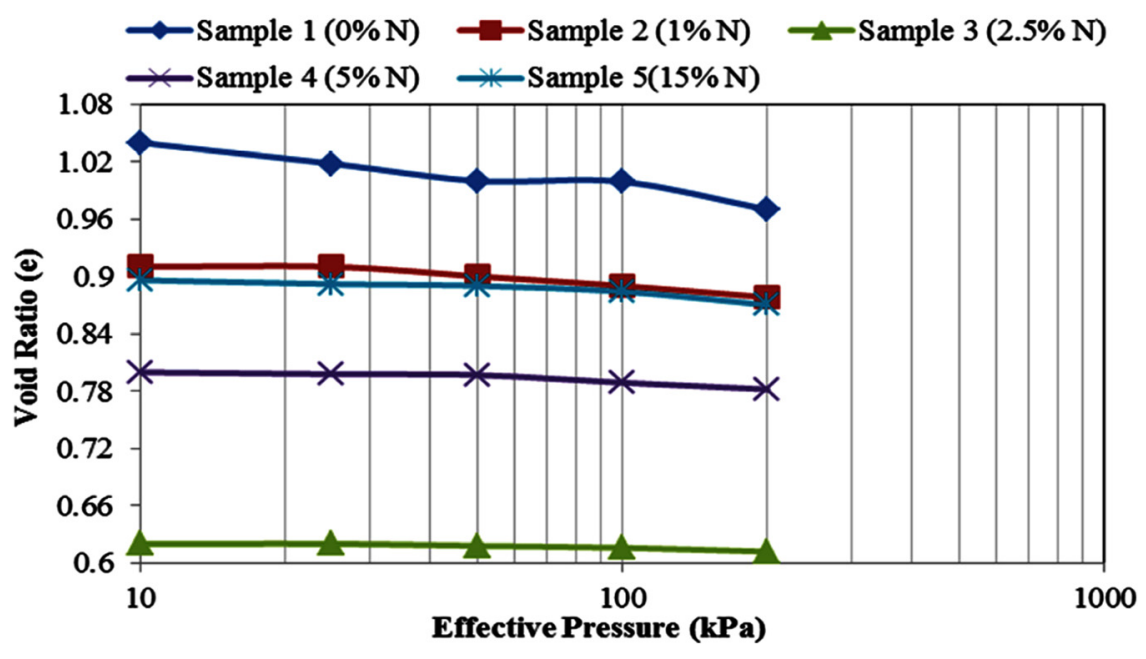

calcium hydroxides crystallize out of solution and finally lead to the production of calcium silicate hydrate (C-S-H), which improves the compressibility parameters of fibrous peat $[14,15]$.

A polymerization process takes place to form a gel when sodium silicate is mixed with soil. This gel makes the binder behave as a glue to bond the soil particles together and as a filler to reduce the void ratio of the soil.

\section{Conclusions}

Based on the results, the following conclusions can be drawn:

- Settlement, $C_{\alpha}$, and $e$ decreased gradually with an increase in cement and kaolinite content. The effect of increased cement content was more significant than the effect of increased kaolinite content.

- All the parameters measured also decreased with an increasing percentage of sodium silicate binder until an optimum value was achieved. After the optimum percentage, an increase in the sodium silicate content increased the compressibility parameters.

- Regarding the effects of cement and sodium silicate (within $3 \%$ ) on the samples, the research showed that when the percentages of these compounds were increased, the compressibility parameters of fibrous peat improved. This happens because the hydration of cement and the fast reaction between cement and sodium silicate causes hydrated calcium silicates to be formed, both via precipitation of silicate ions of the additive and via release of silicate and aluminate ions from the clinker.

\section{ACKNOWLEDGMENTS}

The writers express their gratitude to the Ministry of Science, Technology Innovation, Malaysia (Project No. 03-01-04SF0889) for the financial support for this study.

\section{References}

[1] Anderssonl, R., "Hydraulic Cement Based Binders for Mass Stabilization of Organic Soils," J. L. Hanson and R. J. Termaat, Eds., Geotechnical Special Publication No. 112, Soft Ground Technology Conference, Noordwijkerhout, the Netherlands, ASCE, Reston, VA, 2001, pp. 158-169.

[2] Edil, T. B., "Improvement of Peat: a Case History," Proceedings of the Eighth European Conference on Soil Mechanics and Foundation Engineering, Helsinki, Finland, 1983, pp. 739-744.

[3] Jones, A., "Ground Improvement: For Peat's Sake," Ground Eng., Vol. 39, No. 7, 2006, pp. 22-23.

[4] Jarvis, M. G., Allen, R. H., Fordham, S. J., Hazelden, J., Moffat, A. J., and Sturdy, R. G., "Soils and Their use in South East England," Bulletin of the Soil Survey of Great Britain No. 15, Harpenden, England, 1984.

[5] Haan, E. J. D. and Kruse, G. A. M., "Characterization and Engineering Properties of Dutch Peats. Characterization and Engineering Properties of Natural Soils," Proceedings of 2nd International Workshop, Singapore, Taylor \& Francis, London, 2006, pp. 2101-2133.

[6] Hampton, M. B. and Edil, T. B., "Strength Gain of Organic Ground with Cement-type Binders," Geotechnical Special Publication No. 81, Sessions of ASCE Annual Convention, Boston, Massachusetts, Oct 18-21, Geo-Institute of ASCE, ASCE, Reston, 1998, pp. 135-148.

[7] Kazemian, S., Asadi, A., Huat, B. B., Prasad, A., and Rahim, I. B., "Settlement Problems in Peat Due to Their High Compressibility and Possible Solution Using Cement Columns," C. Shen-en, A. D. de Leon, A. M. Dolhon, M. J. Drerup, and K. Parfitt, Eds., Forensic Engineering, ASCE, Reston, VA, 2009.

[8] Kazemian, S., Huat, B., Prasad, A., and Barghchi, M., "A State of Art Review of Peat from General Perspective," Int. J. Phys. Sci., Vol. 6, No. 8, 2011, pp. 1988-1996.

[9] Kazemian, S., Prasad, A., Huat, B., Bazaz, J. B., Mohammed, T., and Aziz, F. A., "Effect of Aggressive pH Media on Peat Treated by Cement and Sodium Silicate 
Grout," J. Central South Univ. Technol., Vol. 18, No. 3, 2011, pp. 840-847.

[10] Kazemian, S., Prasad, A., Huat, B. B. K., and Barghchi, M., "A State of Art Review of Peat from Engineering Perspective," Int. J. Phys. Sci., Vol. 6, No. 8, 2011, pp. 1974-1981.

[11] Eisazadeh, A., Kassim, K. A., and Nur, H., "Characterization of Phosphoric Acid- and Lime-stabilized Tropical Lateritic Clay," Environ. Earth Sci., Vol. 63, No. 5, 2011, pp. 1057-1066.

[12] Kassim, K. A., "Lime Stabilized Malaysian Cohesive Soils," Jurnal Kejuruteraan Awam, Vol. 16, No. 1, 2004, pp. 13-23.

[13] Eisazadeh, A., Kassim, K. A., and Nur, H., "Stabilization of Tropical Kaolin Soil with Phosphoric Acid and Lime," Nat. Hazards, Vol. 61, No. 3, 2012, pp. 931-942.

[14] Ali, F. H., "The Flow Behaviour of Deformed Prefabricated Vertical Drains," Geotext. Geomembranes, Vol. 10, No. 3, 1991, pp. 235-248.

[15] Ali, F. H., Adnan, A., and Choy, C. K., "Use of Rice Husk Ash to Enhance Lime Treatment of Soil," Can. Geotech. J., Vol. 29, No. 5, 1992, pp. 843-852.

[16] Sing, W. L., Hashim, R., and Ali, F. H., "Unconfined Compressive Strength of Cemented Peat," Aus. J. Basic Appl. Sci., Vol. 3, No. 4, 2009, pp. 3850-3856.

[17] Huat, B. B. K., Prasad, A., Asadi, A., and Kazemian, S., Geotechnics of Organic Soils and Peat, Taylor \& Francis, London, 2014.

[18] Huat, B. B., Kazemian, S., and Kuang, W. L., "Effect of Cement-Sodium Silicate Grout and Kaolinite on Undrained
Shear Strength of Reinforced Peat," Electron. J. Geotech. Eng., Vol. 16, 2011, pp. 1221-1228.

[19] Jarrett, P., "Geoguide 6. Site Investigation for Organic Soils and Peat," JKR Document No. 20709-0341-95, Public Works Department, Kuala Lumpur, Malaysia, 1995.

[20] Edil, T. B. and Fox, P. J., "Field Test of Thermal Precompression," Geotechnical Special Publication (GSP) No. 40, Geo-Institute (G-I) College Station, Texas, 1994, pp. 1274-1286.

[21] DenHamer, D. A., Venmans, A. A. M., Van Der Zon, W. H., and Olie, J. J., "Stabilization of Peat by Silica Based Solidification," M. Hamza, M. Shahien, and Y. El-Mossallamy, Eds., Proceedings of the 17th International Conference on Soil Mechanics and Geotechnical Engineering, The Academia and Practice of Geotechnical Engineering, Alexandria, Egypt, Oct 5-9, IOS Press, Amsterdam, the Netherlands, 2009, pp. 2224-2227.

[22] ASTM D1997-13: Standard Test Method for Laboratory Determination of the Fiber Content of Peat Samples by Dry Mass, Annual Book of ASTM Standards, ASTM International, West Conshohocken, PA, 2013.

[23] BS 1377 Part 6: British Standard Institution Code of Practice for Foundation, British Standard Institution, London, 1990.

[24] von Post, L., Sveriges Geologiska Undersvknings torvinventering och negra av dess hittills vunna resultat, "Sveriges Geologiska Undersvknings torvinven-tering och negra av dess hittills vunna resultat [Geological survey of sweden peat inventory and some of its hitherto missing results]," 1922 (in Swedish). 